\title{
SELECTION OF FUNGAL ISOLATES WITH POTENTIAL FOR PHOSPHATE SOLUBILATION AND FORMULATION OF INOCULANT FOR COFFEE CROPS
}

\author{
Sara Maria Chalfoun ${ }^{1}$, Caroline Lima Angélico², Mário Lúcio Vilela de Resende \\ Graziella Evaristo de Moraes ${ }^{4}$
}

(Received: April 22, 2019; accepted: July 11, 2019)

\begin{abstract}
The dependence on chemical fertilizers for the future of agriculture will result in additional soil health losses, possibility of water contamination and continued currency avoidance due to the increasing dependence on imports. The indiscriminate use of synthetic fertilizers has polluted the soil and watersheds, destroying useful microorganisms and insects, what makes crops more susceptible to diseases. Considering this critical scenario, microorganisms have stood out as a potential alternative for maintaining the productivity, reliability and sustainability of the global food chain. In order to increase the productivity and/or reduce the amount of fertilizers, as well as to meet the requirements for the use of low-solubility phosphorus sources, microorganisms were isolated from the rhizosphere and artificially cultivated. Subsequently, they were selected regarding their potential for solubilizing phosphorus and incorporated into a low-cost matrix. A microbial inoculant was thus developed and tested in a coffee crop. It was possible to formulate an inoculant based on an isolate selected from Aspergillus niger, using an inactivated seed and sodium alginate as matrices. It was also observed that there was a greater correlation between the evaluated parameters and increasing doses of the inoculants when Araxá apatite was used as source of phosphorus, proving the importance of the inoculants as release factors and availability of phosphorus in the case of sources less soluble, giving Brazilian agriculture greater autonomy in the input market.
\end{abstract}

Indexing terms: Sustainability, Aspergillus niger, Penicillium spp, citric acid,phosphatase.

\section{SELEÇÃO DE ISOLADOS FÚNGICOS COM POTENCIAL PARA SOLUBILIZAÇÃO DE FOSFATO E FORMULAÇÃO DE UM INOCULANTE PARA A CULTURA DO CAFÉ}

RESUMO: A dependência por fertilizantes químicos para o futuro da agricultura resultará em perdas adicionais de saúde do solo, possibilidade de contaminação da água e evitação continuada da moeda devido à crescente dependência das importações. O uso indiscriminado de fertilizantes sintéticos poluiu o solo, bacias hidrográficas, destruiu microrganismos e insetos úteis e tornou as lavouras mais suscetíveis a doenças. Diante deste cenário crítico, os microrganismos têm se destacado como uma alternativa potencial para manter a produtividade, confiabilidade e sustentabilidade da cadeia alimentar global. Com o intuito de aumentar a produtividade e / ou reduzir a quantidade de fertilizantes, bem como atender às exigências do uso de fontes de fósforo de baixa solubilidade, microrganismos foram isolados da rizosfera e cultivados artificialmente. Posteriormente, foram selecionados por seu potencial solubilizador de fósforo e incorporados em uma matriz de baixo custo. Um inoculante microbiano foi desenvolvido e testado na cultura do café e os resultados mostraram que foi possível formular um inoculante baseado em um isolado selecionado de Aspergillus niger, usando uma semente inativada e alginato de sódio como matrizes. Os melhores resultados no desenvolvimento das plantas foram obtidos utilizando um inoculante de sementes inativado e o fungo A. niger aplicado a $15 \mathrm{~g}$ por planta para o fertilizante de apatita Araxá. A mesma dosagem foi eficiente para as duas matrizes testadas quando o fertilizante Single Super Phosphate foi usado.

Termos para indexação: Sustentabilidade, Aspergillus Níger, Penicillium spp, ácido cítrico, fosfatase.

\section{INTRODUCTION}

Phosphorus $(\mathrm{P})$ is an element that deserves special importance because the absence of this nutrient in the tropical soils cultivated with coffee is common, which, in general, have low phosphorus content available and predominance of acidity. Moreover, this nutrient is quickly fixed by the clay fraction in Brazilian soils, forming less soluble compounds (Laviola et al., 2007), that is why only $5 \%$ to $20 \%$ of the soluble $\mathrm{P}$ applied is available to the crop, with the rest being used or not, depending on the $\mathrm{P}$ reaction in the soil.
These characteristics, summed to the high rates of phosphorus adsorption, have been considered the most severe limitations for the cultivation in these soils and consequently for the increase of productivity, since applications of high dosages of phosphorus are required.

It is important to consider that phosphates are scarce and non-renewable natural resources and, therefore, they should be more efficiently used. The availability of soluble phosphorus for the application of natural phosphates is subject to their slow solubilization, what limits the

\footnotetext{
${ }^{1,4}$ Empresa de Pesquisa Agropecuária de Minas Gerais/EPAMIG SUL - Campus UFLA - Cx. P.176 - 37.200-000 - Lavras - MG chalfoun@epamig.ufla.br, graziella.moraes@agronomia.ufla.br

${ }^{2,3}$ Universidade Federal de Lavras - Instituto Nacional de Ciência e Tecnologia do Café/INCT CAFÉ - Cx. P. 3037 - 37.200-000

Lavras-MG - carolineoi@oi.com.br,mlucio@dfp.ufla.br
} 
application in fast growing crops, thus requiring a prior treatment with phosphorus solubilizing microorganisms (Sharma et al., 2013; Mahanta et al., 2014).

On the other hand, the excessive use of conventional phosphorus fertilizers to improve agricultural productivity to meet the constantly increasing global food demand, potentially causes surface and ground water pollution, waterway eutrophication, soil fertility depletion and accumulation of toxic elements, such as high concentrations of selenium (Se) and arsenic (As) in the soil (Alori et al., 2017).

In contrast to the difficulty of phosphate absorption by plants, microorganisms have proven to be an exceptionally rich source of useful products, which vary greatly in terms of their biological activity and structural complexity. The inoculation of phosphate solubilizing microorganisms or the management of their populations has been suggested as a way to replace or reduce the use of soluble phosphate fertilizers, by means of the better utilization of existing or added natural phosphates to the soil and those formed by the application of soluble sources. Soil microorganisms, including bacteria and fungi, solubilize non-available inorganic forms of $\mathrm{P}$. These microorganisms use biochemical strategies, such as the production of organic acids, or a mechanism that involves microbial growth and favors the secretion of protons $(\mathrm{H}+)$ (Richardson \& Simpson, 2011; Jain et al., 2012, Krishnananda \&Dipika, 2017).

Among the solubilizing fungi of phosphates, the genera Aspergillus and Penicillium deserve mention. The solubilization efficiency differs between genera and families of microorganisms. Many cases have been observed in which the efficiency of fungi is more evident, although solubilizing bacteria are found in greater number (Alori et al., 2017). The microorganisms involved in the solubilization of phosphates can also contribute to the plant growth through other mechanisms, for example, by increasing the solubilization, posteriorly improving the efficiency of biological nitrogen fixation (Wani et al., 2007).

It is verified that phosphorus is the limiting factor for nitrogen fixation by the rhizobia-legume symbiosis, increasing the availability of other elements or producing substances that promote plant growth. Solubilization results from decreased $\mathrm{pH}$ or secretion of metabolites as organic and inorganic acids (Seshachala \& Tallapragada,
2012).The action of the inoculant on the phosphate solubilization occurs through the hydrolytic activity of the organic acids and production of the enzyme phosphatase, thus allowing the insoluble phosphorus to become soluble and available in the soil (Zhu et al., 2011).

In bioprocesses, microorganisms have been microencapsulated or immobilized seeking among other factors, increasing stability and maintaining viability of the crop (Górak and ŻYMAŃCZYK, 2017). Different methods of cellular immobilization, including porous matrix entrapment, such as alginate gel, have been proposed in order to obtain cells with high activity and stability. Researches show that sodium alginate is the most widely used bipolymer for immobilization and is considered an efficient support mainly for the immobilization of microbial cells (LIMA, 2011; TRABELSI et al., 2014).

The present research aimed to develop and test aninoculant based on a phosphate solubilizing microorganism encapsulated in two different ways andtwo phosphorous sources to mitigate the problem of phosphorus availability and acquisition by the plant in the coffee crops.

\section{MATERIAL AND METHODS}

This research was carried out in four steps:

Obtaining isolates of Aspergillus spp. and Penicillium spp.

Soil samples from organic coffee cultivation with $26,3 \mathrm{mg} / \mathrm{dm} 3$ of $\mathrm{P}$ were collected in a farm with four years of cultivation in the organic system localizated in Santo Antônio do Amparo - MG, packed and transported to the Laboratory of Applied Microbiology of the EcoCentro / EPAMIG, and the isolates were obtained by the serial dilution method (Silva et al., 2001). Later, $250 \mu \mathrm{L}$ of the solution was inoculated into $9 \mathrm{~cm}$ Petri dishes containing 2\% MA culture medium and the plates were incubated in BOD at $25^{\circ} \mathrm{C}$ with photoperiod of 12 hours. After the development of the microorganisms of interest, the colonies were purified in $2 \%$ MA culture medium for later inoculation in the specific culture media aiming the identification of the species and verification of the potential for phosphate solubilization.

\section{Evaluation of mycelial growth rate index (IVCM) and ochratoxin A production}

The rate of mycelial growth rate was determined according to the formula described by Oliveira (1991): 
$\mathrm{IVCM}=\Sigma(\mathrm{D}-\mathrm{Da}) / \mathrm{N}$

In which:

IVCM = mycelial growth rate index

$\mathrm{D}=$ current mean diameter of the colony

$\mathrm{Da}=$ mean diameter of the colony in the previous day

$\mathrm{N}=$ number of days after inoculation.

The determination of ochratoxin A production potential was made using the Plug Agar method, as described by Filtenborg \& Frisvad (1980. The isolates presenting the set of favorable characteristics were selected. The importance of the use of a non-producing ochratoxin $\mathrm{A}$ isolate is due to the non-favoring of the increase of the inoculum of the fungus in the soil, being considered the main contaminant toxin of the coffee.

In vitro evaluation of the production of acids, citric acid, phosphatase and phosphate solubilization potential and by means of submerged fermentation

\section{In vitro evaluation of isolates for acid production}

Mycelial disks of fungi were cultivated in CREA medium (creatine $3 \mathrm{~g} / \mathrm{L}$, sucrose $30 \mathrm{~g} / \mathrm{L}$, $0.5 \mathrm{~g} / \mathrm{L} \mathrm{KCl}, 0.01 \mathrm{~g} / \mathrm{L} \mathrm{MgSO}_{4} \cdot 7 \mathrm{H}_{2} \mathrm{O}, 1.3 \mathrm{~g} / \mathrm{L}$ $\mathrm{K}_{2} \mathrm{HPO}_{4} \cdot 3 \mathrm{H}_{2} \mathrm{O}, 0.05 \mathrm{~g}$ of purple bromocresol, $15 \mathrm{~g} /$ $\mathrm{L}$ of agar). The plates were incubated with no light for 96 hours at $28{ }^{\circ} \mathrm{C}$ with daily monitoring. The appearance of a bright yellow halo evidenced the production of cyclopiazonic acid or other related alkaloids, according to Samson \& Frisvad (2004).

\section{In vitro evaluation of isolates for the production of citric acid}

The evaluation was performed using the methodology described by Foster (1949). The medium used had the following composition: $5 \mathrm{~g} / \mathrm{L}$ glucose; $1 \mathrm{~g} / \mathrm{L}$ peptone; $1 \mathrm{~g} / \mathrm{L} \mathrm{KH}_{2} \mathrm{PO}_{4}$; $0.5 \mathrm{~g} / \mathrm{L} \mathrm{MgSO}_{4} ; 15 \mathrm{~g} / \mathrm{L}$ of Agar and $65 \mathrm{~mL}^{2} / \mathrm{L}$ of Bromocresol Green solution $(0.5 \mathrm{~g}$ Bromocresol Green in $7 \mathrm{~mL}$ of $0.1 \mathrm{~N} \mathrm{NaOH})$. The $\mathrm{pH}$ was adjusted to 4.5. The plates were incubated for 96 hours at $28{ }^{\circ} \mathrm{C}$ with daily monitoring. The appearance of a bright yellow halo evidenced the production of citric acid in the medium tested.

\section{In vitro evaluation of phosphatase production}

The isolates of Aspergillus niger and Penicillium billai obtained were evaluated in order to determine the capacity of phosphate solubilization in vitro, according to the methodology proposed by Sylvester-Bradley et al. (1982), which determines the capacity of solubilization of phosphate characterized by the formation of a transparent halo formed around the colonies.

\section{Solubilization efficiency of the isolates by submerged fermentation}

Araxá apatite and Single Super Phosphate fertilizers at $3 \mathrm{~g} / \mathrm{L}$ in GL culture medium (glucose, yeast extract) were used to evaluate the phosphate solubilization capacity of selected microorganisms. Aliquots of $1 \mathrm{~mL}$ of the spore suspension at the concentration of $10^{6}$ of each isolate were transferred to Erlenmeyers containing $100 \mathrm{~mL}$ of culture medium, with treatments as follows: 1-culture medium, 2-culture medium + Araxá apatite, 3- culture medium + Single Super Phosphate, 4- Culture medium + Penicillium billai, 5- culture medium + Aspergillus niger, 6- culture medium + Araxá apatite + Penicillium billai, 7- culture medium + Single Super Phosphate+ Penicillium billai, 8- culture medium + Araxá apatite + Aspergillus niger, 9- culture medium + Single Super Phosphate+ Aspergillus niger. Treatments were performed in triplicate and incubated at $28{ }^{\circ} \mathrm{C}$ under shaking at $190 \mathrm{rpm}$ for seven days. Subsequently, the supernatant was filtered on Whatman $\mathrm{N}^{\circ} 4$ filter paper. The quantification of soluble phosphorus was conducted at the Water Analysis Laboratory of Federal University of Lavras. The $\mathrm{pH}$ of different treatments was determined according to the Association of Official Analytical Chemistry (AOAC) technique (1992).

\section{Evaluation of different matrices for the encapsulation of Aspergillus niger}

Sodium alginate pellets produced according to the method adapted from Lewis \& Papavizas (1985)and some seeds were tested to evaluate the best matrix for the encapsulation of the most promising isolates, for solubilization of phosphate and other characteristics. After analyzing the development of the microorganism in the substrate, the most economically feasible support medium that provided the greatest development of the isolates was chosen.

\section{Application of the selected isolates in the phosphate solubilization of coffee plants}

Tests started under with a sprinkler irrigation system from the best matrices selected. 
Before the installation of the research, an analysis of the soil used was carried out and, in the face of the results, the quantities of nutrients required for the crop were calculated based on the recommendations of the 5th Approach (1999). The nitrogen requirement of the culture was supplied by the application of Ammonium Sulphate and those of potassium by Potassium Chloride. Moreover, phosphorus was supplied by high solubility phosphate (Single Super Phosphate) and low solubility phosphate (Araxá apatite).

Coffee seedlings used in the experiment corresponded to six months old, Catuaí cultivar, the most cultivated in Brazil, obtained from a nursery registered with the MAPA(Ministry of Agriculture, Livestock and Food Supply), therefore, conducted according to the Good Practices of Nutrition and Phytosanitary Control, located in the city of Nepomuceno, Minas Gerais, Brazil. The experiment was installed in pots with capacity for 8 liters of soil in a completely randomized design with four replicates.

\section{Inoculum Aspergillus niger}

The experiment was carried out in four replicates, in a completely randomized design, as described below: 1- Araxá apatite without inoculant; 2-Araxá apatite $+5 \mathrm{~g}$ inactivated seed inoculant; 3 - Araxá apatite $+10 \mathrm{~g}$ inactivated seed inoculant; 4- Araxá apatite $+15 \mathrm{~g}$ inactivated seed inoculant; 5- Araxá apatite $+5 \mathrm{~g}$ Alginate pellets inoculant; 6- Araxá apatite $+10 \mathrm{~g}$ alginate pellets inoculant; 7 - Araxá apatite $+15 \mathrm{~g}$ alginate pellets inoculant, 8- Single Super Phosphate, without inoculant; 9 - Single Super Phosphate+ $5 \mathrm{~g}$ seed inactivated inoculant; 10 - Single Super Phosphate $+10 \mathrm{~g}$ seed inactivated inoculant; 11 Single Super Phosphate $+15 \mathrm{~g}$ Seed Inactivated Inoculant; 12 - Single Super Phosphate $+5 \mathrm{~g}$ Alginate Pellets Inoculant; 13- Single Super Phosphate $+10 \mathrm{~g}$ Alginate Pellets Inoculant; 14 Single Super Phosphate+ $15 \mathrm{~g}$ Alginate Pellets Inoculant.

Analyses of plant height, stem diameter and root length were performed at the end of one year for the evaluation of the efficiency of the tested isolate.

\section{RESULTS AND DISCUSSION}

Obtaining isolates of Aspergillus sp. and Penicilium sp.

The isolates were morphologically identified as belonging to the genus Penicillium according to the key proposed by Frisvad \& Samson, 2004 and Aspergillus according to Samson, et al., 2014).after the morphological identification the isolates were sent to complement the molecular identification and deposited in the Collection of Culture of Microorganisms of the Department of Food Science (CCCDA).

Overall, 40 isolates of Aspergillus niger and 20 isolates of Penicillium spp. were identified. Only one Penicillium billai isolate was identified and two were identified as Penicillium citrinum and the others were considered Penicillium spp.

\section{Evaluation of mycelial growth rate index (IVCM) and mycotoxin production}

It was observed by means of the index of mycelial growth rate that the fungus $A$. niger $(0.48 \mathrm{~cm})$ developed faster than $P$. billai $(0.41 \mathrm{~cm})$, a relevant characteristic for the best biotechnological use of the fungus (Figure 1).

Regarding the production of mycotoxins, the absence of production of Ochratoxin A was observed for the isolates A. niger and P. billai. However, the production of citrinin by $P$. citrinum isolates under ultraviolet light with $\lambda 366 \mathrm{~nm}$ wavelength in CAMAG (UF-BETRACHTER) chromate monitor (Figure 2) was observed.

In vitro evaluation of the production of acids, citric acid, phosphatase and phosphate solubilization potential and by means of submerged fermentation.

\section{In vitro evaluation of isolates for acid production}

The potential for acid production by the fungi tested showed a superiority of Aspergillus niger in relation to Aspergillus billai (Figures 3 and 4), since the modes of action of the microorganisms on the solubilization of the parameters from decreased $\mathrm{pH}$ or secretion of metabolites as organic and inorganic acids (Seshachala \& Tallapragada, 2012).

Figure 3 shows that the $A$. niger isolate (A) had a high acid production potential, while the $P$. billai isolate (B) did not indicate this potential.

Figure 4 shows the formation of a halo for the production of citric acid by the isolates $A$. niger (A) and P. billai (B). It is observed that both produced citric acid, but with distinct intensity for $A$. niger. 


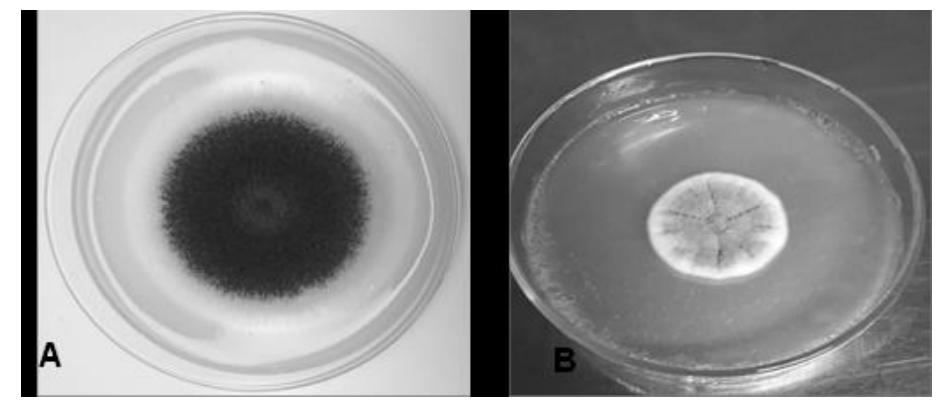

FIGURE 1 - Colonies of A. niger (A) and P. billai (B) with 7 days of development.

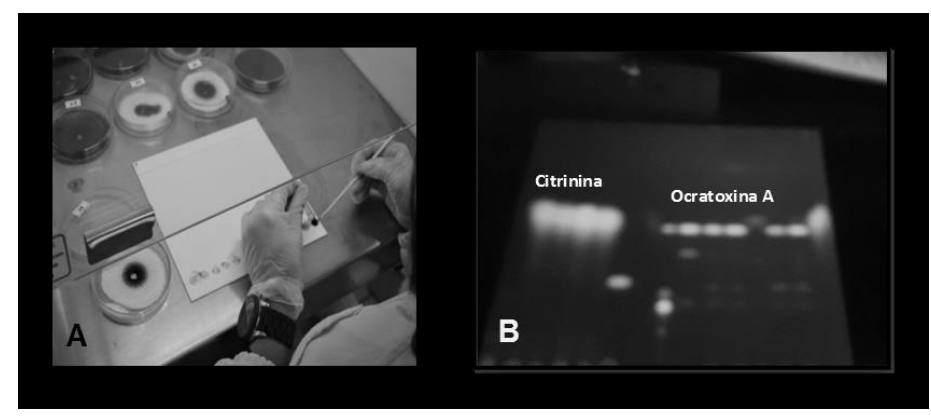

FIGURE 2 - Test of mycotoxin production by the Plug Agar method: (A) Installation of the test; (B) Chromatovisor reading: citrinin production by $P$. citrinum isolates and absence of OTA production by A. niger.

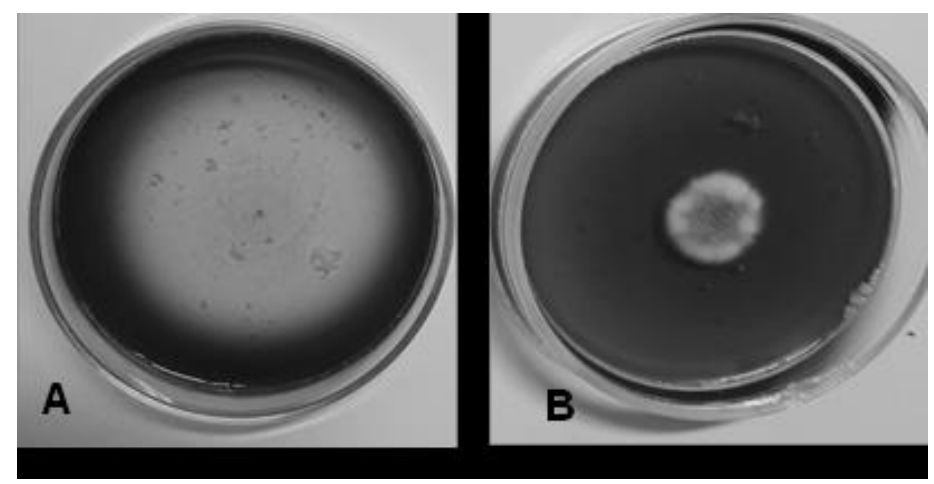

FIGURE 3 - Production of acids by isolates: (A) A. niger and (B) P. billai.

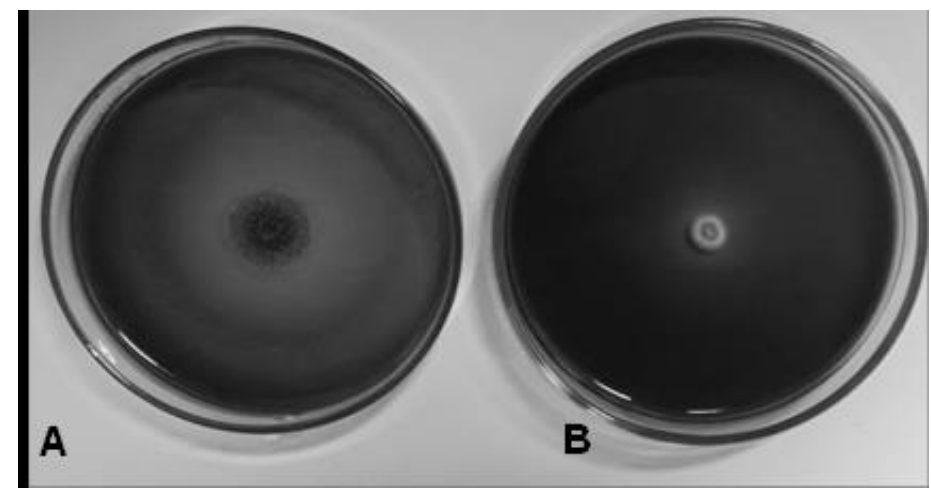

FIGURE 4 - Citric acid production by isolates of (A) A. niger and (B) P. billai. 


\section{In vitro evaluation of phosphatase production}

The action of the inoculant on the phosphate solubilization occurs through the hydrolytic activity of the organic acids and production of the enzyme phosphatase, thus allowing the insoluble phosphorus to become soluble and available in the soil (Zhu et al., 2011).

The phosphate solubilization potential evaluation by A. niger and P. billai isolates showed that only the treatment in which calcium phosphate was added showed the production of phosphatase by the isolates, represented by the formation of a translucent halo around the colony, more evident for A. niger Figure 5.

\section{Efficiency of solubilization of the isolates by submerged fermentation}

In liquid medium, Aspergillus niger had a high effect on the solubilization of phosphorus in the Araxá apatite phosphate form, about three times higher than the control (without the inoculant). The isolate was also responsible for the reduction of $\mathrm{pH}$ in relation to controls without inoculation.

In relation to P. billai, the results concerning the solubilization of phosphate in liquid medium confirmed the in vitro tests. Therefore, the present research was carried out with the isolate of Aspergillus niger.

Table 1 shows the results regarding the confirmation of the solubility of phosphorus of the selected isolate in the previous step.

The study by Chuang et al. (2007) demonstrated the positive correlation between phosphate and acidity. According to these authors, there is a need for acid production to occur the solubilization, which mechanism was also reported by Vassilev et al. (2006), with citric acid being considered a solubilizer. According to Barroso \& Nahas (2008) the increase in the titratable acidity leads to a decrease in the final $\mathrm{pH}$ levels, corresponding to an increase of the soluble phosphate content.

\section{Evaluation of different matrices for the encapsulation of the isolates}

The different matrices tested showed the same efficiency in terms of fungus viability (Figure 6), indicating the potential of inactivated seeds as a lower cost alternative (BASHAN et al., 2014).

\section{Application of the selected isolates in the phosphate solubilization of coffee plants}

\section{Inoculum Aspergillus niger}

Figure 7 presents the inoculants of A. niger obtained by means of the matrices of sodium alginate (A) and inactivated seed (B).

The results of the evaluation regarding the effect of inoculants application are presented in Figure 8 at 11.

According to the results presented in Figures 8 and 9, with the use of Single Super Phosphate, it was observed that the treatment with inoculants 1 and 2 did not present significant differences in relation to plant height and stem diameter and significant positive correlation for the length of roots.

When the source of phosphorus used was Araxá apatite, a significant positive correlation was observed with respect to all parameters evaluated when inoculants were obtained from inactivated seeds (Figures 10 (A), 10 (B) and (10C). In addition, when the inoculant was obtained from sodium alginate pellets, and positive correlations were observed for plant height (Figure 11A) and root length (Figure 11B).

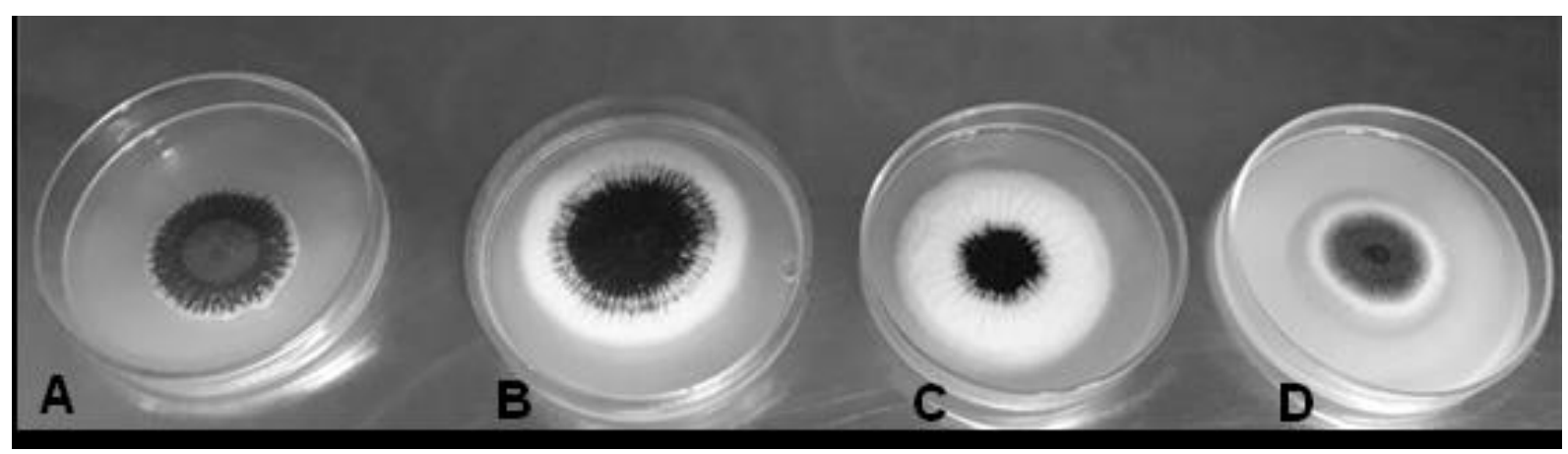

FIGURE 5 - Test of phosphatase production by A. niger isolate: (A) Control, (B) Araxá apatite, (C) Single Super Phosphate and (D) Calcium Phosphate 
TABLE 1 - Solubility of phosphorus in liquid medium by the fungus $A$. niger and P. billai

\begin{tabular}{lcccc}
\hline Treatments & \multicolumn{2}{c}{ Aspergillus niger } & \multicolumn{2}{c}{ Penicillium billai } \\
& $\mathbf{p H}$ & soluble $\mathbf{P}(\mathbf{m g} / \mathbf{L})$ & $\mathbf{p H}$ & soluble $\mathbf{P}(\mathbf{m g} / \mathbf{L})$ \\
\hline Culture medium & 6.31 & 02.93 & 6.31 & 2.93 \\
Culture medium + AA* & 5.29 & 17.72 & 5.29 & 17.72 \\
Culture médium + SS** & 4.82 & 71.09 & 4.82 & 71.09 \\
Culture medium + fungo & 3.83 & 3.14 & 5.00 & 3.02 \\
Culture medium + AA + fungi & 3.98 & 51.47 & 5.39 & 17.63 \\
Culture medium + SS + fungi & 3.69 & 48.47 & 4.98 & 52.10 \\
\hline
\end{tabular}

*AA-Araxá apatite

**SS- Single Super Phosphate

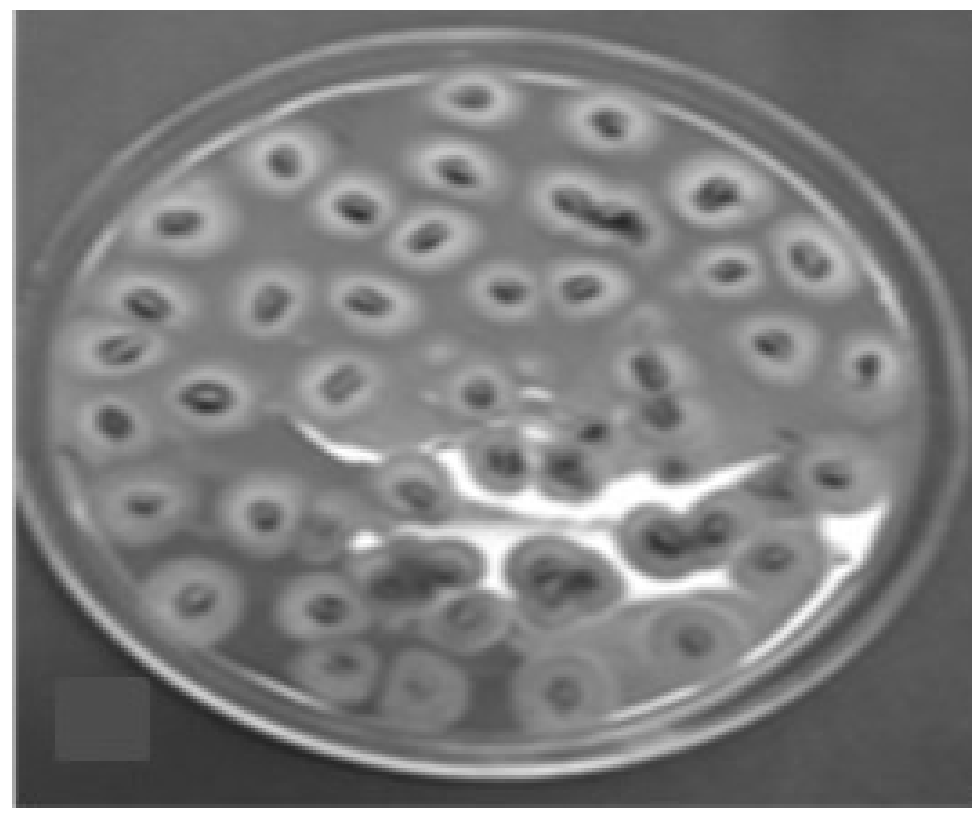

FIGURE 6 - Viability of $A$. niger isolate formulated with inactiveted seed matrix.

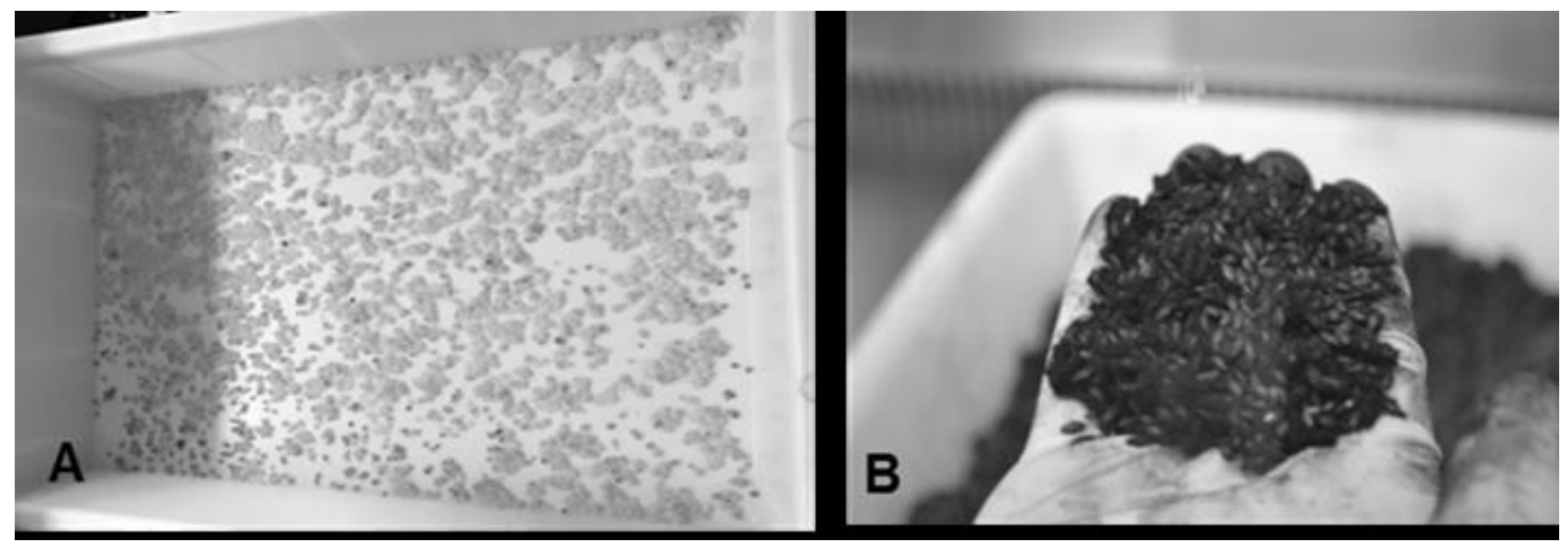

FIGURE 7 - A. niger inoculant in matrices of sodium alginate (A) and inactivated seed (B). 


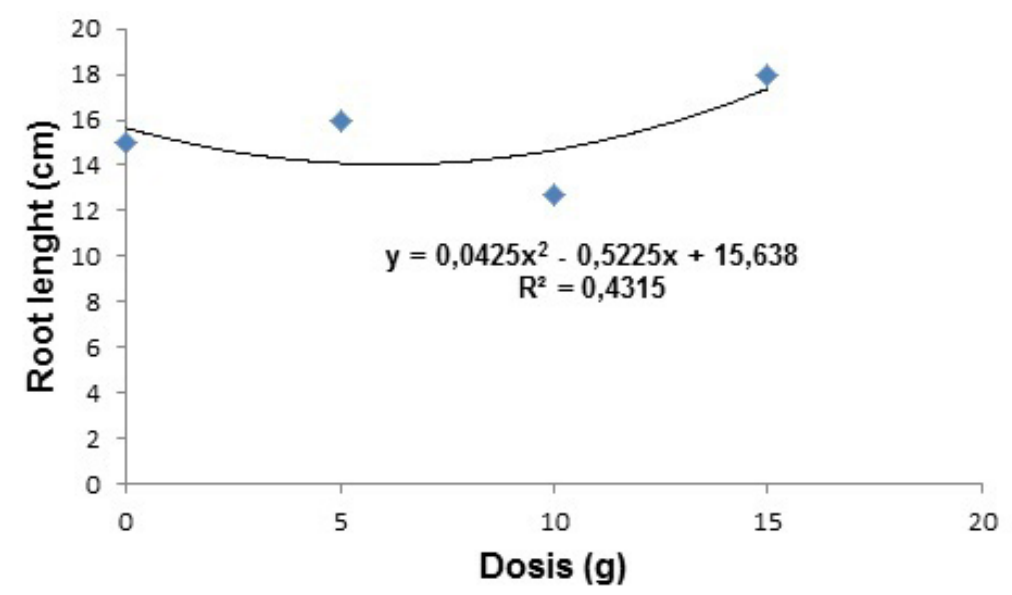

FIGURE 8 - Effect of inoculant based on inactivated seeds on the root length of 12 month old coffee plants using the Single Super Phosphate fertilizer as source of P.

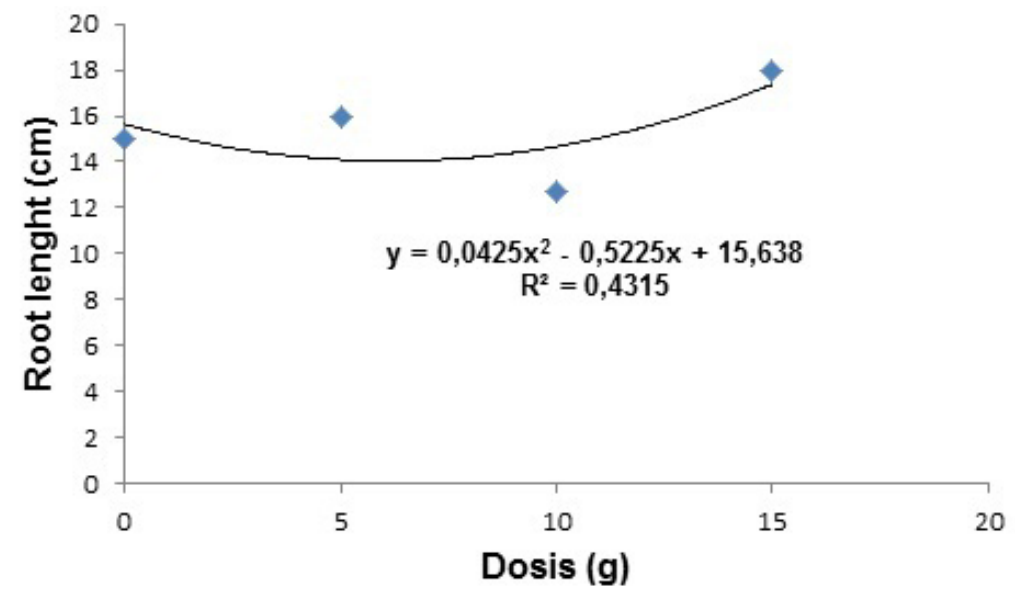

FIGURE 9 - Effect of inoculant based on sodium alginate pellets on the root length of 12 month-old coffee plants using Single Super Phosphate fertilizer as the source of P.

The inoculants tested in the present study promoted better development of the plants at the highest tested dose $(15 \mathrm{~g})$ independent of the source of phosphorus used, confirming previous data on the importance of the role of microorganisms in increasing the availability of phosphorus to plants (Torres and Prager, 2013 ; Sisneros et al., 2016) Krishnananda \& Dipika, 2017).

The results confirm the solubilizing potential of the A. niger fungus initially selected for its higher potential for the production of the enzyme phosphatase and citric acid, confirming previous work (Richardson \& Simpson, 2011).

In the case of sodium alginate encapsulation and the use of an inactivated seed, it was observed that although sodium alginate is a more used matrix for the encapsulation process of microorganisms (LIMA, 2011; TRABELSI et al., 2014), results similar in relation to the development of the plants, but with a significantly lower cost were observed by the use of an inactivated seed.

It was also observed that there was a greater correlation between the evaluated parameters and increasing doses of the inoculants when Araxá apatite was used as source of phosphorus, proving the importance of the inoculants as release factors and availability of phosphorus in the case of sources less soluble, giving Brazilian agriculture greater autonomy in the input market. 

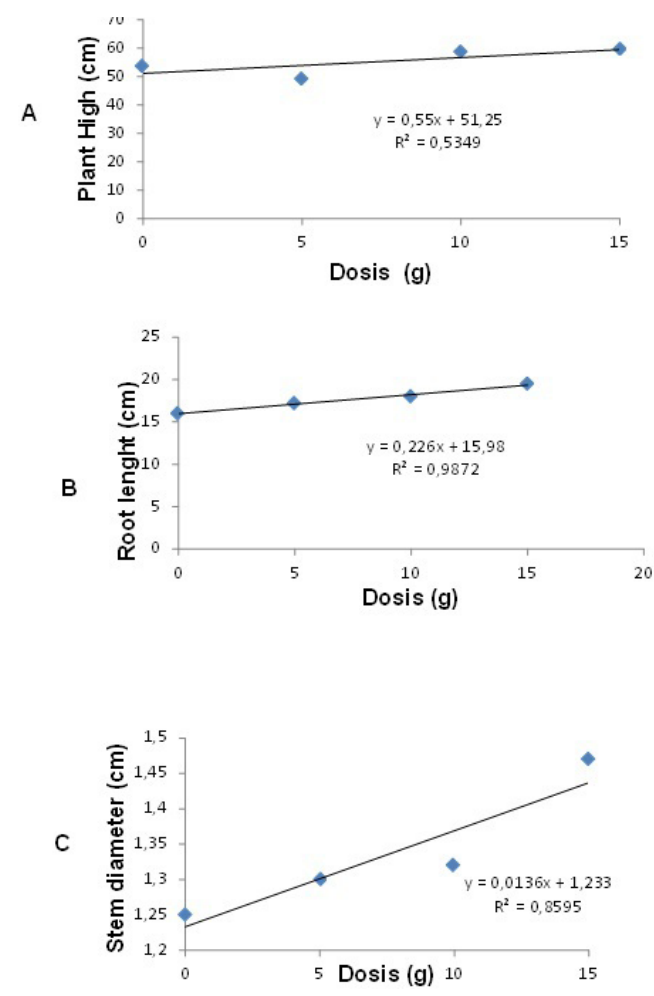

FIGURE 10 - Effect of inactivated seed inoculants on plant height (A), root length (B) and stem diameter (C) parameters in 12-month-old plants using Araxá apatite.
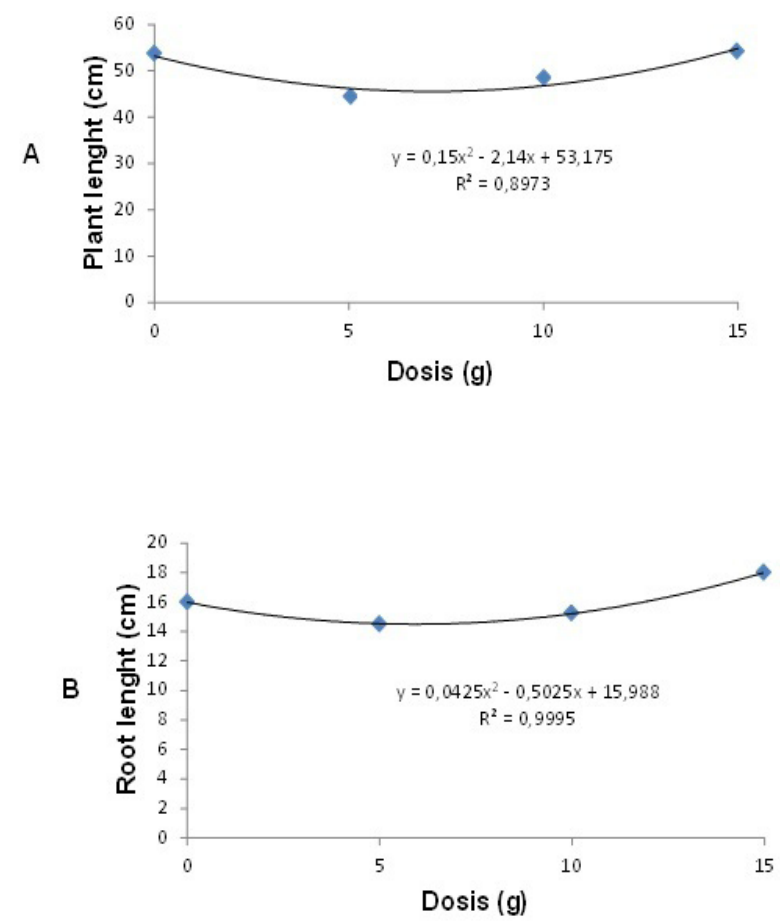

FIGURE 11 - Effect of sodium alginate pellets on plant height (A) and root length (B) parameters in 12-month-old plants using Araxá apatite as the source of $\mathrm{P}$. 


\section{CONCLUSIONS}

Phosphorous solubilization tests of Araxá apatite (low solubility) and Single Super Phosphate (soluble) from microorganisms prospected, indicated the superiority of A. niger fungus in relation to the $P$. billai isolates.

It was possible to formulate an inoculant based on an isolate selected from Aspergillus niger using inactivated seed and sodium alginate as matrices.

The best results on the development of plants were obtained by using an inactivated seed inoculant and the A. niger fungus applied at a dosage of $15 \mathrm{~g}$ per plant for the Araxá apatite fertilizer.

\section{ACKNOWLEDGEMENTS}

The authors are grateful to FAPEMIG (Fundação de Amparo à Pesquisa do Estado de Minas Gerais), INCT do Café (Instituto Nacional de Ciência e Tecnologia do Café) for financial support.

\section{REFERENCES}

ALORI, E.T.; GLICK, B.R.; BABALOLA, O. O. Microbial Phosphorus Solubilization and Its Potential for Use in Sustainable Agriculture. Frontiers in Microbiology.; 8:971, 2017.

ASSOCIATION OF OFICIAL ANALYTICAL CHEMISTS. Official methods of analysis of the Association of Official Analytical Chemists.15. ed. Arlington, 1992.

BARROSO, C. B.; NAHAS, E. Solubilização do fosfato de ferro em meio de cultura. Pesquisa Agropecuária Brasileira, Brasília, v. 43, n. 4, p. 529-535, abr. 2008.

BASHAN, Y.; de-BASHAN, L. E.; PRABHU, S. R.; HERNANDEZ, J.P. Advances in plant growthpromoting bacterial inoculant technology: formulations and practical perspectives. Plant Soil. v. 378, p. 1-33, 2014.

CHUANG, C.C., KUO, Y.L., CHAO, C.C. \& CHAO, W.L. Solubilization of inorganic phosphates and plant growth promotion by Aspergillus niger. Biology and Fertility of Soils. 43: 575-584, 2007.

ELIZEI, V. G. Avaliação da viabilidade de fungos encapsulados e armazenados em diferentes temperaturas. 2009. 50 p. Dissertação (Mestrado em Microbiologia) - Universidade Federal de Lavras, Lavras, 2009.
FIELTENBORG, O.; FRISVAD, J.C.A. A simple screening method for toxigenic moulds in pure cultures. Lebensmittel Wissenschaft und Technologie, London, v.13, p.128-130, 1980.

FOSTER, J. W. Chemical Activities of Fungi. Academic Press, New York, 1949.

FRISVAD, J. C.; SAMSON, R. A. Polyphasic taxonomy of Penicillium subgenus Penicillium. A guide to identification of food and air-borne terverticillate Penicillia and their mycotoxins. Studies in Mycology, v. 49, n. 1, p. 174, 2004.

GÓRAK, M.; ŻYMAŃCZYK, E. D. Reductive Activity of Free and Immobilized Cells of Cyanobacteria toward Oxophosphonates - comparative Study. Journal of Applied Phycology, v.29, n.1, p. 245-253, 2017.

\section{J.A.LEWIS,G.C.PAPAVIZAS. Characteristics of alginate pellets formulated} with Trichoderma and Gliocladium and their effect on the proliferation of the fungi in soil. Plant Pathology, 34, p. 571-577, 1985.

INGLE, K.P.; PADOLE, D.A. Review Article Phosphate Solubilizing Microbes: An Overview, International Journal of Current Microbiology and Applied Sciences, v.6, n.1, p. 844-852, 2017.

LAVIOLA,B.G.; MARTINEZ, H.E.P.;SOUZA,R.B. de; ALVAREZ VENEGAS,V.H. Dinâmica de cálcio e magnésio em folhas e frutos de cafeeiro arábico em três níveis de adubação. Revista Brasileira de Ciência do Solo.v.31,p, 319-329, 2007.

RICHARDSON, A.E.; SIMPSON, R.J. Soil microorganisms mediating phosphorus availability update on microbial phosphorus. Plant Physiology. v.156, n.3, p.:989-996, 2011.

RIBEIRO, A.C., GUIMARÃES, P.T.G. \& ALVAREZ, V.V.H. (Eds.). Recomendações para o uso de corretivos e fertilizantes em Minas Gerais - $5^{\text {a }}$ aproximação. Viçosa, Comissão de Fertilidade do Solo do Estado de Minas Gerais, 1999, 359p.

LIMA, Daniel Teixeira. Efeito crioprotetor de lactose e glicose em células fúngicas imobilizadas em alginato de sódio como método de preservação de culturas. 2011. 99 f. Dissertação (Mestrado em Microbiologia Médica) - Faculdade Medicina, Universidade Federal do Ceará, Fortaleza, 2011. 
RODRIGUES, C. Desenvolvimento de bioprocesso para produção de ácido cítrico por fermentação no estado sólido utilizando polpa cítrica. 2006. 107 p. Dissertação (Mestrado em Processos Biotecnológicos) - Universidade Federal do Paraná, Curitiba, 2006.

SAMSON RA, VISAGIE CM, HOUBRAKEN J, et al. Phylogeny, identification and nomenclature of the genus Aspergillus. Studies in Mycology, v. 78, p.141-73, 2014.

SANTOS, R. R. M. Aproveitamento do caroço do açaí como substrato para a produção de enzimas por fermentação em estado sólido. 2010.83 p. Dissertação (Mestrado em Biotecnologia) - Universidade Federal de São Carlos, São Carlos, 2010.

SESHACHALA, U.; TALLAPRAGADA, P. Phosphate solubilizers from the rhizosphere of Piper nigrum L. in Karnataka, India. Chilean Journal of Agricultural Research, v. 72, p. 397-403, 2012.

SILVA, N. da; JUNQUEIRA, V. C. A.; SILVEIRA, N. F. A. Manual de métodos de análise microbiológica de alimentos. 2. ed. São Paulo: Livraria Varela, 317p., 2001.

SISNEROS R., C.A.; SÀNCHEZ de P., M.; MENJYVAR R., J. C. Influencia de microorganismos solubilizadores de fosforo del suelo y su absorción por plántulas de café. Bioagro, v.28, n.2, p.95-106, 2016.

SLIVINSKI, C. T. Produção, purificação parcial e caracterização bioquímica de glucoamilase de Aspergillus niger obtida por fermentação em estado sólido. 2007. 70 p. Dissertação (Mestrado em Ciência e Tecnologia de Alimentos) - Universidade Estadual de Ponta Grossa, Ponta Grossa, 2007.
SYLVESTER-BRADLEY, R.; ASAKAWA, N.; LA TORRACA, S.; MAGALHÃES, F.M.M.; OLIVEIRA, L.A. \& PEREIRA, R.M. Levantamento quantitativo de microrganismos solubilizadores de fosfatos na rizosfera de gramíneas e leguminosas forrageiras na Amazônia. Acta Amazonica, v. 12, p. 15-22, 1982.

TORRES, C.P.; PRAGER, M.S.de. Efecto de la aplicación de roca fosfórica y la inoculación con bacterias solubilizadoras de fosfatos sobre el crecimiento del ají (Capsicum annum L.) Acta Agronómica, v. 63, p. 136-144, 2014.

TRABELSI,I.,AVADI,D.; BEJAR, W.; CHOUAYEKH, H.; BEN, S.R. Effects of Lactobacillus plantarum immobilization in alginate coated with chitosan and gelatin on antibacterial activity. International Journal of Biological Macromolecules, v.64, p.84-89,2014.

VASSILEV, N., MEDINA, A., AZCÓN, R. \& VASSILEVA, M. Microbial solubilization of rock phosphate on media containing agro-industrial wastes and effect of the resulting products on plant growth and P uptake. Plant and Soil, v. 287, p. 77-84, 2006.

WANI, P. A.; KHAN, M. S.; ZAIDI, A. Co-inoculation of nitrogen fixing and phosphate solubilizing bacteria to promote growth, yield and nutrient uptake in chickpea. Acta Agronomica Hungarica, v.55, p. 315-323, 2007.

ZHU, F.; QU, L.; HONG, X.; AND SUN, X. Isolation and characterization of a phosphate solubilizing halophilic bacterium Kushneria sp. YCWA18 from Daqiao Saltern on the coast of yellow sea of China. Evidence-based Complementary and Alternative Medicine, 6 p., 2011. 